\title{
LA PERSPECTIVA DE GÉNERO EN LA COMPRENSIÓN DE LA MASCULINIDAD Y LA SOBREVIVENCIA INDÍGENA EN MÉXICO
}

\author{
GENDER PERSPECTIVE IN THE COMPREHENSION OF INDIGENOUS MASCULINITY AND \\ SURVIVAL IN MÉXICO
}

\author{
Rufino Díaz-Cervantes* \\ Campus Puebla. Colegio de Postgraduados. Km. 125.5 Carr. Fed. México-Puebla, Momoxpan, \\ San Pedro Cholula, Puebla. 72760. (rufinodiazcervantes@yahoo.com.mx)
}

\begin{abstract}
RESUMEN
Este trabajo propone un marco teórico para orientar la aprehensión de los matices patriarcales y heterosexistas de las masculinidades indígenas en México y Latinoamérica, cuyos contextos son la supervivencia y reproducción en condiciones de marginalización. Parte de reflexionar sobre algunos aportes de los estudios de género y de las masculinidades, en general de la academia feminista, que enfatizan sobre la perspectiva de género. Discute la importancia de abordar la relación existente entre etnia y género para entender procesos históricos que intervienen en la construcción del sujeto indígena contemporáneo y plantea la necesidad de superar al discurso de la dualidad de género en función de probar la existencia de la diversidad genérica, invisibilizada y reprimida por la vigencia de sistemas simbólicos, que evidencian particularidades de la masculinidad hegemónica y la dominación masculina indígenas. Se concluye que la interpretación de la masculinidad indígena requiere ser estudiada respecto a sus significados y prácticas originarias, sus resistencias y alianzas con las socializaciones occidentales, sus consecuencias para la sobrevivencia y reproducción indígena, particularizada en sus afectaciones a mujeres, hombres y en otras identidades genéricas reprimidas, además de advertir sus trascendencias en el medio ambiente.
\end{abstract}

Palabras clave: dominación masculina, etnia, género, heterosexismo, indígenas, masculinidad hegemónica, masculinidades, supervivencia indígena.

\section{INTRODUCCIÓN}

El problema que plantea el estudio de las masculinidades indígenas en México y Latinoamérica

\footnotetext{
* Autor responsable $*$ Author for correspondence. Recibido: mayo, 2014. Aprobado: julio, 2014. Publicado como ARTÍCULO en ASyD 11: 359-378. 2014.
}

This paper proposes a theoretical framework to guide the understanding of the patriarchal and heterosexist nuances of indigenous masculinities in México and Latin America, whose contexts are survival and reproduction in marginalized conditions. It begins by reflecting upon some of the contributions made by gender and masculinity studies, and feminist academia in general, that emphasize the gender perspective. It discusses the importance of addressing the existing relationship between ethnicity and gender in order to understand historical processes that intervene in the construction of the contemporary indigenous subject. It also suggests the need to overcome the discourse of gender duality in favor of ascertaining the existence of gender diversity, albeit made invisible and repressed by the validity of symbolic systems which evidence particularities of indigenous hegemonic masculinity and masculine domination. The paper concludes that the interpretation of indigenous masculinity requires being studied in terms of its original meanings and practices, its resistances and alliances with western socializations, and its consequences for indigenous survival and reproduction, characterized by its affectation on women, men and other repressed gender identities, in addition to noting its transcendence for the environment.

Key words: masculine domination, ethnicity, gender, heterosexism, indigenous peoples, hegemonic masculinity, masculinities, indigenous survival.

\section{INTRODUCTION}

The problem presented by the study of indigenous masculinities in México and Latin America

eminist theory has revealed that "men" and
"women" are gender construction processes
that are legitimized as conventional models 
$\mathrm{L}$ a teoría feminista ha revelado que "hombres" y "mujeres" son procesos de construcción de género, los cuales se legitiman como modelos convencionales a sistemas simbólicos permeados por significaciones e intereses patriarcales y heterosexistas (Maffia, 2006). Como tales, se expresan en formas particulares de acuerdo con los momentos históricos y con la organización de las sociedades humanas influenciadas por clase, etnia y generación, etcétera (Kimmel, 1998), donde el género se identifica como una categoría social que transversaliza a toda esa organización. En este tenor, cabe preguntarse cuáles son las particularidades y trascendencias de los sistemas de género aludidos en contextos indígenas, qué características reúne el proceso de subjetivación masculina en varones indígenas, cómo se articulan esos procesos con la sobrevivencia y reproducción indígena contemporánea, y qué consecuencias acarrea para mujeres, hombres, otras identidades genéricas y el medio ambiente originarios. Sin embargo, cualquier investigación centrada en estas interrogantes y en contextos indígenas en México y Latinoamérica requiere esclarecer y establecer puntos de referencia epistemológicos, teóricos y metodológicos que contribuyan a interpretar esas realidades. Por tanto, este trabajo constituye una propuesta en esos sentidos.

La metodología utilizada se fundamentó en una revisión, discusión y reflexión discursiva de la perspectiva de género orientada desde postulados feministas y descoloniales, además de otros aportes, con los cuales se busca superar las aproximaciones desde el dualismo de género. Para superar esa forma de percibir e interpretar los ordenamientos de género en contextos indígenas se propone cuestionar la vigencia del patriarcado y el heterosexismo, dado que son sistemas simbólicos que convencionalmente organizan, reproducen y refuerzan modelos de masculinidad y feminidad y que, además, promueven su hegemonía y los consolidan como esencias, limitando su comprensión y transformación.

Además, exige hacer énfasis en las influencias de la occidentalización entre los pueblos indígenas, evidenciando que esos sistemas simbólicos han sido refinados a través de los mecanismos de homogenización, aculturación o asimilación nacionalista, que en general promueven y acentúan significados y valoraciones occidentales, forzando la emergencia de identidades indígenas resignificadas y sobrevivientes bajo condiciones de alta fragilización ${ }^{1}$ económica, for symbolic systems permeated by patriarchal and heterosexist significations and interests (Maffia, 2006). As such, they express themselves in particular ways according to historical moments and to the organization of human societies influenced by class, ethnicity, and generation, etc. (Kimmel, 1998), where gender is identified as a social category that transverses all of this organization. Thus, one may ask which are the particularities and transcendences of gender systems alluded to in indigenous contexts, what characteristics are amassed by the process of masculine subjectification in indigenous males, how these processes are articulated in contemporary indigenous survival and reproduction, and what consequences may arise for native women, men, other gender identities, and the environment. However, any research centered on these questions and on indigenous contexts in México and Latin America requires elucidating and establishing epistemological, theoretical, and methodological reference points that contribute to an interpretation of these realities. As a result, this paper constitutes a proposal to that end.

The methodology used was based on a revision, discussion, and discursive reflection of the gender perspective oriented from feminist and de-colonial positions, as well as other contributions with which it is sought to surpass approaches stemming from gender dualism. In order to overcome this way of perceiving and interpreting gender systems in indigenous contexts, it is proposed that the validity of patriarchy and heterosexism be questioned, since they are symbolic systems that conventionally organize, reproduce, and reinforce models of masculinity and femininity, and which, in addition, promote their hegemony and consolidate them as essentialities, limiting their comprehension and transformation.

Moreover, this calls for an emphasis on the influences of westernization among indigenous populations, evidencing that those symbolic systems have been refined through mechanisms of homogenization, acculturation or nationalist assimilation that generally promote and accentuate western meanings and values, forcing the emergence of re-signified indigenous identities that survive under conditions of high economic, political, cultural, and environmental fragilization ${ }^{1}$, all of which also reassert their ethnification, genderization, and masculinization under subotherness conditions. 
política, cultural y ambiental las que, además, reafirman su etnicización, generización y masculinización en condiciones subalterizadas.

En este sentido se propone a la perspectiva de género como el posicionamiento epistemológico, teórico y metodológico que facilite entender el carácter relacional, diverso y complejo del sujeto indígena, y que lo coloque como parte y resultado de un proceso constante y conflictivo de la socialización de sistemas simbólicos occidentales y las resistencias colectivas de la identidad indígena. Para ello se busca que dicha perspectiva continúe, desde luego, orientada desde las aspiraciones feministas pero, además, alimentada por aquellos aportes catalogados como descoloniales y de otros discursos de los que han contribuido a que los estudios de las masculinidades se fortalezcan.

\section{LOS ESTUDIOS DE LAS MASCULINIDADES Y LA PERSPECTIVA DE GÉNERO EN LA COMPRENSIÓN DE LAS MASCULINIDADES INDÍGENAS eN MéXICO y LATINOAMÉrica}

En los últimos diez años el estudio de "la(s) masculinidad(es)" o del género de los hombres ha llegado a proponerse como uno de los ejes estratégicos de la epistemología y teoría social contemporánea. Ramírez (2009:16) señala que su importancia radica en que gran parte de ellos parten desde una perspectiva de género, derrotero central de la teoría feminista, la cual: "refleja el potencial explicativo del género para analizar la forma como los hombres participan y se relacionan en sociedad, a la vez que proporciona una dimensión nueva sobre los espacios que ocupan y la manera cómo lo hacen".

Los estudios de las masculinidades con perspectiva de género articulan diversos campos estratégicos, entre ellos las limitantes y las posibilidades de justicia social, la equidad, la igualdad de género y el reconocimiento de la diversidad genérica, entre otros. Pese a que algunas contribuciones, como los de Díaz, (2012); Pérez-Nasser (2011); López (2010); Núñez (2009); Pérez (2002), entre otros(as), han visibilizado diversas situaciones de las masculinidades indígenas, es necesario exponer que aún se requieren de grandes esfuerzos investigativos.

Estudiar los significados y prácticas de las masculinidades indígenas sugiere admitir que, al igual que en Occidente, en los Pueblos indígenas existe una diversidad de experiencias y expresiones de masculinidad y
In this sense, gender perspective is proposed as an epistemological, theoretical and methodological viewpoint that facilitates an understanding of the relational, diverse and complex character of the indigenous subject, placing it as the result and part of a constant and conflictive process of socialization of western symbolic systems alongside the collective resistance of indigenous identity. To that end, it is sought for this perspective to continue guided by feminist aspirations, naturally, but also fed by contributions catalogued as de-colonial as well as other discourses that have aided in the strengthening of masculinities studies.

\section{MASCULINITIES STUDIES AND GENDER PERSPECTIVE IN THE COMPREHENSION OF INDIGENOUS MASCULINITIES IN MÉXICO AND LATIN AMERICA}

During the last ten years, the study of "masculinity(ies)" or male gender has positioned itself as one of the strategic axes of contemporary social theory and epistemology. Ramírez (2009:16) points out that its importance lies in that a large part of them stem from a gender perspective, the central route of feminist theory, which: "reflects the explicative potential of gender to analyze the way in which men participate and relate in society, and at the same time provides a new dimension over the spaces they occupy and how they do so."

Masculinities studies with a gender perspective articulate diverse strategic fields, among them the limitations and possibilities of social justice, equity, gender equality, and the recognition of gender diversity, among others. Although certain contributions like those by Díaz (2012), Pérez-Nasser (2011), Núñez (2009), and Pérez (2002), among others, have made diverse situations of indigenous masculinities visible, it is necessary to illustrate that great investigative efforts are still required.

Studying the meanings and practices of indigenous masculinities seems to allow that, as in the West, in indigenous peoples there is a diversity of experiences and expressions of masculinity and of being men. However, in contrast to the West, these are constructed under an ethnicity constrained by the weight of colonization, resilience and the re-signification of the original ancestry.

It is therefore considered that the angles in approaching the study of masculinities under 
de ser hombres. Sin embargo, a diferencia de Occidente, éstas se construyen bajo una etnicidad constreñida por los pesos de la colonización, las resiliencias y las re-significaciones de la ancestralidad originaria.

Por tanto, se considera que las orientaciones en los acercamientos al estudio de las masculinidades en contextos occidentales podrían partir, como lo sugiere Huberman (2013), de un vínculo estrecho con el discurso y la práctica de los "derechos humanos". En el caso de los pueblos indígenas el estudio de las masculinidades requiere contemplar su relación con los derechos colectivos originarios ${ }^{2}$ y de las problemáticas de la supervivencia y reproducción (Díaz, 2012), el empoderamiento de las mujeres (Díaz, 2014), la salud y diversidad sexual (Núñez, 2006), el medio ambiente, la migración (Díaz, 2012; HernándezSánchez, 2009), y un sinfín de campos cuyo estudio podría contribuir a solventar la mejoría de la condición y posición étnica y de género en los pueblos indígenas.

En este sentido las lecturas que se hagan sobre la masculinidad indígena desde la perspectiva de género requieren que, además de considerar el carácter relacional y diverso del género, se deslinde de posicionamientos colonialistas y de intereses occidentales ${ }^{3}$ para revertir las comparaciones que se hacen frecuentemente con las sociedades, puesto que al privilegiar los ideales tácitos de "civilidad" y "civilización" occidental se reafirma la etnicización, "barbarización", inferiorización o minorización étnica del sujeto indígena.

Posicionar la perspectiva de género, orientada con una intencionalidad descolonial, como eje epistémico, teórico y metodológico en los estudios de las masculinidades, permite revelar que la internalización de contenidos simbólicos occidentales, alimentados del patriarcado y el heterosexismo, han disuelto, trastocado, potenciado y resignificado los sistemas simbólicos de etnia y género, reproduciendo en ellas formas específicas de modelos, estructuras y relaciones (Mott, 2006). Entre los discursos descoloniales se proponen los desarrollados por De Sousa (2009) y Dussel (2005). El primero habla de la necesidad de orientar los estudios de las realidades latinoamericanas desde una epistemología del Sur ${ }^{4}$, mientras que el segundo plantea el concepto del "Despliegue del Sistema-mundo occidental" ", con el cual se descubren las influencias de la socialización sobre la pervivencia material e inmaterial indígena. Otras alternativas western contexts could sprout from a close link to the discourse and practice of "human rights", as Huberman (2013) suggests. In the case of indigenous peoples, the study of masculinities requires contemplating their relationship with original collective rights ${ }^{2}$ and the difficulties of survival and reproduction (Díaz, 2012), women empowerment (Díaz, 2014), health and sexual diversity (Núñez, 20016), the environment, migration (Díaz, 2012; Hernández-Sánchez, 2009), and countless other fields whose study could contribute to resolving the improvement of ethnic and gender condition and position in indigenous peoples.

In this sense, interpretations made of indigenous masculinity from the gender perspective require, in addition to considering the relational and diverse character of gender, to separate from viewpoints representing colonial and western interests ${ }^{3}$, in order to revert the comparisons frequently made with societies, because when the tacit ideals of western "civility" and "civilization" are privileged, the ethnification, "barbarization," inferiorization, or ethnic minoritization of the indigenous subject are reaffirmed.

Positioning the gender perspective, guided with a de-colonial intentionality, as an epistemic, theoretical, and methodological axis in masculinities studies reveals that the internalization of western symbolic contents, fed by patriarchy and heterosexism, has dissolved, disrupted, strengthened, and re-signified the symbolic systems of ethnicity and gender, reproducing within them specific forms of models, structures, and relations (Mott, 2006). Among decolonial discourses, those developed by De Sousa (2009) and Dussel (2005) are proposed. The first suggests the need to direct studies of Latin American realities from an epistemology of the South ${ }^{4}$, while the second asserts the concept of the "Deployment of the western world-system" ", with which the influences of socialization on material and immaterial indigenous survival are discovered. Other pertinent alternatives, particularly to guide the theoretical-methodological issue, are those elaborated by Foucault (1977) regarding genealogical historization. His proposal contributed in understanding the surviving indigenous subject as a phenomenon emerging from a web of conflicts and negotiations.

Nevertheless, the understanding of indigenous masculinities through the proposal presented is a 
pertinentes, sobre todo para orientar la cuestión teórico-metodológica, son las elaboradas por Foucault (1977) respecto a la historización genealógica. Su propuesta contribuye a entender al sujeto indígena sobreviviente como un fenómeno emergente de un entramado de conflictos y negociaciones.

Sin embargo, la aprehensión de las masculinidades indígenas a través de la propuesta aludida es una cuestión compleja, llena de retos y de dificultades. Por ejemplo, querer decantar las influencias occidentales requiere tomar en cuenta los amortiguamientos de las resistencias y resiliencias indígenas ${ }^{6}$, los encuentros y desencuentros simbólicos occidentales e indígenas, desde donde se moldean y reproducen tanto la hegemonía occidental como la subalteridad indígena. Tal situación descubre un contexto de filiaciones étnicas y de género, indígenas y occidentales superpuestos. Otras disyuntivas a ser superadas son las dificultades para advertir procesos de cambio o transformación del orden generizado indígena, como productos históricos o generacionales ${ }^{7}$. También de aquellos significados y prácticas diferenciadas de género indígenas, con frecuencia opacadas por categorías epistémicas y analíticas que aún no se liberan de miopías colonizantes. Enfrentar estos desafíos remite a la necesidad de entender las trascendencias de los contenidos y significados de categorías teóricas como las de etnia y género.

\section{ETNIA Y GÉNERO EN LA COMPRENSIÓN DE LAS MASCULINIDADES Y DEL SUJETO DIVERSO INDÍGENAS}

El estudio de las masculinidades indígenas conduce necesariamente a la revisión de las vinculaciones entre las categorías de etnia y género, dado que a través de ellas es posible visualizar las diferenciaciones que establecen en los sistemas simbólicos, representaciones y prácticas de la masculinidad en los pueblos originarios. La introducción del concepto de etnia sacude la vigente concepción biologicista de raza y sus aplicaciones estereotipadas y racializantes que sostienen el universalismo del sujeto occidental. Como alude Eng (2008:96), la inclusión de la etnicidad en los estudios de las masculinidades: “...supone un gran reto para la masculinidad hegemónica dado que la raza cuestiona el concepto de universalismo y particularismo. El sujeto universal, el varón blanco y heterosexual, ya está particularizado en cierto modo, complex issue, full of challenges and difficulties. For example, the desire to lean into western influences requires taking into account the absorption of indigenous resistance and resilience ${ }^{6}$, the indigenous and western symbolic encounters and non-encounters, from which western hegemony and indigenous subordination are molded and reproduced. Such a situation unveils a context of ethnic and gender affiliations, the indigenous and the western superimposed. Other quandaries to be overcome are the difficulties in observing processes of change or transformation in the indigenous gender order, as historical or generational products ${ }^{7}$. Also, gender differentiated indigenous meanings and practices frequently obscured by epistemic and analytical categories that have not yet been freed from colonizing shortsightedness. Facing these challenges remits to the need of understanding the transcendences of the contents and meanings of theoretical categories like ethnicity and gender.

\section{ETHNIC GROUP AND GENDER IN THE COMPREHENSION OF MASCULINITIES AND THE DIVERSE INDIGENOUS SUBJECT}

The study of indigenous masculinities necessarily leads to the review of correlations between the categories of ethnic group and gender, since through them it is possible to visualize the differentiation they establish in the symbolic systems, representations and practices of masculinities in native peoples. The introduction of the concept of ethnic group shocks the current biologicist conception of race and its stereotypical and racializing applications upon which the universalism of the western subject is sustained. As Eng (2008:96) points out, the inclusion of ethnicity in masculinities studies: "...entails a great challenge for the hegemonic masculinity since the race issue questions the concept of universalism and particularism. The universal subject, the white and heterosexual male, is already particularized to a certain degree, but the notion of race leads us to reflect beyond any universalist presumption. Ethnicity, just as women's studies, challenges the hegemonic". Therefore, to interweave the categories of ethnic group and gender seeks to reveal the symbolic context of particularities and the processes of construction, significance and exercise of indigenous masculinity. 
pero la noción de raza nos lleva a reflexionar más allá de cualquier presunción universalista. Lo étnico, al igual que los estudios de la mujer, desafía lo hegemónico". Por tanto, hilar las categorías de etnia y género busca develar el contexto simbólico de las particularidades y los procesos de construcción, significación y ejercicio masculino indígenas.

Con el concepto de género se plantea explicar los procesos que definen la subjetividad de las y los sujetos en función de lo construido como "masculino" y "femenino". Se parte de considerar que estos universos de género son altamente influidos por los sistemas simbólicos, políticos e ideológicos del patriarcado, el heterosexismo (Guasch, 2000) y el capitalismo (Herrera, 2005), cuyos códigos culturales, políticos, económicos e ideológicos constituyen los principales medios de subjetivación del sujeto en Occidente; es decir, moldean el ser y deber ser de "hombre(s)" y "mujer(es)". Además, legitiman estructuras, instituciones y relaciones de poder, reproducción y catexis ${ }^{8}$ (Connell, 1995).

La categoría teórica de género es fundamental para revelar que, si bien las subjetividades de género se elaboran a partir de las diferenciaciones biológicas (Rubin, 1997), su vinculación con las trascendencias étnicas, entre otras categorías, deja ver que son una construcción sociocultural histórica-contextual que logra significados y prácticas variadas. Al respecto, Kimmel (1998:210) señala que: "los significados de la masculinidad varían en las distintas culturas, a lo largo de la historia, entre hombres de una misma cultura, y en el transcurso de la vida. Esto significa que no podemos hablar de la masculinidad como si fuera una constante, una esencia universal, sino más bien como una articulación fluida y en constante cambio, de significados y comportamientos. En este sentido, debemos hablar de masculinidades, reconociendo así las diferentes definiciones que construimos acerca de lo que significa ser hombre. Al pluralizar el término, reconocemos que la masculinidad tiene significados diferentes para distintos grupos de hombres en diversos momentos".

Más en concreto, Núñez, (2006:50-51) explica que: "...la masculinidad o la hombría no es una posición de subjetividad ni una identidad del poder patriarcal, estable y homogénea. ... los varones no somos todos iguales, ... hay diferencias internas profundas y relaciones de poder entre hombres: por clase, etnia, preferencias sexuales, identidades de género (más
With the concept of gender, explaining the processes that define the subjectivity of male and female subjects is proposed, in function of what is constructed as "masculine" and "feminine". It begins from considering that these gender universes are highly influenced by symbolic, political and ideological systems of patriarchy, heterosexism (Guasch, 2000) and capitalism (Herrera, 2005), whose cultural, political, economic and ideological codes constitute the principal means of subjectivation of the subject in the West; that is, they shape the being and they must be "man (men)" and "woman (women)". Also, they legitimize the structures, institutions and relations of power, reproduction and cathexis ${ }^{8}$ (Connell, 1995).

The theoretical category of gender is fundamental to reveal that, although gender subjectivities are elaborated from biological differentiations (Rubin, 1997), their correlation with ethnic transcendences, among other categories, demonstrates that they are a historical-contextual sociocultural construction that attains varied meanings and practices. In this regard, Kimmel (1998:210) points out that: "the meanings of masculinity vary in different cultures, throughout history, between men of the same culture, and during a lifetime. This means that we cannot speak of masculinity as if it were a constant, a universal essence, but rather as a fluid articulation, in constant change, of meanings and behaviors. In this sense, we must speak of masculinities, thus recognizing the different definitions that we construct around what it means to be a man. When pluralizing the term, we recognize that masculinity has different meanings for different groups of men at different moments".

More concretely, Núñez (2006:50-51) explains that: "...masculinity or manliness is not a position of subjectivity or an identity of the patriarchal, stable and homogenous power...not all males are the same...there are profound internal differences and power relations among men: from class, ethnicity, sexual preferences, gender identities (more or less masculine, more or less feminine), educational level, occupation, rural/urban origin, among other elements". This suggestion allows understanding that gender diversity exists, even, in the homogenization that is made of "man" and in the collective imaginary of "machismo".

Therefore, the relational approach of categories such as ethnicity and gender, among others, allows recognizing gender diversity under different contexts, 
o menos masculino, más o menos femenino), nivel educativo, ocupación, origen rural/urbano, entre otros elementos". El planteamiento anterior permite entender que la diversidad de género existe, incluso, en la homogenización que se hace del "hombre" y en el imaginario colectivo del "machismo".

Por tanto, el abordaje relacional de categorías como etnia y género, entre otras, permite reconocer la diversidad genérica en diferentes contextos, entre ellos los indígenas. Busca superar el pensamiento del dualismo de género, el cual se limita a evidenciar la institucionalización organizada y significada de los espacios y desigualdades entre los seres humanos. El dualismo de género impone dificultades para entender y aprehender las realidades de género y sus matizaciones. Como lo expone Bourdieu (2007:127): “...estos dualismos, profundamente arraigados en las cosas (las estructuras) y en los cuerpos, no han nacido de un mero efecto de dominación verbal y no pueden ser abolidos por un acto de magia performativa; los sexos no son meros roles que pueden interpretarse a capricho (a la manera de los drag queens), pues están inscritos en los cuerpos y en un universo del cual sacan su fuerza”. Estas consideraciones señalan que cuando se habla de cualquiera de las configuraciones de género dualistas de "hombre" o "mujer", se está refiriendo al orden establecido del género dominante, a las estructuras prevalecientes o renovadas del patriarcado y heterosexismo (Mogrovejo, Salinas y Gargallo, 2006). En Occidente éstas no logran superar sus imágenes antagónicas (Guasch, 2000), mientras que en contextos indígenas son continuamente reconstruidos, retocados y resignificados desde esos patrones (Mott, 2006).

Frente al dualismo de género se busca valorar posturas que contribuyan a entender que no todos los hombres y mujeres ejercitan o son leales por igual a la ideología dominante de género, ni que ésta es única y exclusivamente internalizada y practicada por los varones (Segal, 2008). Como lo plantea Ferrándiz (2002) se requiere reconocer que existe un calidoscopio de género. En este sentido, Valdés y Olavarría (1998), así como Fuller (1998) y otros(as) han evidenciado empíricamente la diversidad de significados y prácticas de ser "hombre" en Latinoamérica. Ante esta realidad, los estudios de las masculinidades invitan cada vez más a superar la idea generalizada del "machismo" como una esencia de la identidad genérica de los hombres. La discusión y la reflexión among them the indigenous. It seeks to surpass the thought of gender dualism, which is limited to evidencing the organized and signified institutionalization of spaces and inequalities among human beings. Gender dualism imposes difficulties to understanding and apprehending the realities of gender and its qualifications. As Bourdieu (2007:127) exposes: “...these dualisms, deeply rooted in things (structures) and in bodies, have not been born out of a mere effect of verbal domination and cannot be abolished by an act of performance magic; the sexes are not mere roles that can be interpreted at whim (like drag queens do), for they are inscribed in the bodies and in an universe from which they derive their strength". These considerations point out that when there is talk of any one of the dualist configurations of gender, of "man" or "woman", they are referring to the order established by the dominating gender, to the prevalent or renewed structures of patriarchy and heterosexism (Mogrovejo, Salinas and Gargallo, 2006). In the West, these do not manage to exceed their antagonistic images (Guasch, 2000), while in indigenous contexts they are continuously reconstructed, retouched and re-signified from these patterns (Mott, 2006).

Facing gender dualism, it is sought to value stances that contribute to understanding that not all men and women exercise or are equally loyal to the dominating gender ideology, or that it is uniquely and exclusively internalized and practiced by males (Segal, 2008). As Ferrándiz (2002) suggests, it is required to recognize that there is a kaleidoscope of gender. In this sense, Valdés and Olavarría (1998), as well as Fuller (1998) and others, have shown empirically the diversity of meanings and practices of being a "man" in Latin America. In face of this reality, masculinities studies increasingly invite to go beyond the generalized idea of "machismo" as an essence of men's gender identity. The discussion and reflection highlighted point to processes of "ethnification" and "genderization" as part of the guiding axes of the historical, theoretic and empirical exploration of indigenous masculinities.

\section{ETHNIFICATION AND GENDERIZATION AS CONTEXTS AND PATHS IN THE ANALYSIS OF INDIGENOUS MASCULINITIES}

Considering that the construction of indigenous masculine subjectivities and their practices are restricted by western sub-otherness, it is proposed 
aludidas apuntan a los procesos de "etnicización" y "generización" como parte de los ejes orientadores de la exploración histórica, teórica y empírica de las masculinidades indígenas.

\section{ETNICIZACIÓN Y GENERIZACIÓN COMO CONTEXTOS Y DERROTEROS EN EL ANÁLISIS DE LAS MASCULINIDADES INDÍGENAS}

Considerando que la construcción de las subjetividades masculinas indígenas y sus prácticas están constreñidas por la subalterización occidental, se propone que su exploración y comprensión considere los escenarios de supervivencia y reproducción histórica. Es decir que se orienten considerando las contradicciones que se dan entre los imaginarios y los estereotipos que sostienen la etnicización y generización indígena. Lo que interesa es apuntar los mecanismos de la alteridad étnica y los reforzamientos de género históricos influenciados por el patriarcado y heterosexismo occidental. Como enfatiza Foucault (1977), desesencializar lo naturalizado requiere advertir aquellos procesos emergentes, aunque éstos sean juzgados como minúsculos, insignificantes y de bajo alcance, e incluso, es fundamental explorar su aparente ausencia?

Los procesos de etnicización se pueden advertir a través de la relectura de diversos aportes sociológicos y antropológicos que han hecho los estudios sobre los pueblos indígenas. Por ejemplo, a través de señalar las condiciones sociales, culturales, económicas, políticas y jurídicas de los pueblos indígenas en Latinoamérica, Peña, Cabedo y López (2002) contribuyen a identificar dicho fenómeno como un producto histórico de complejos constreñimientos en el que la generización se descubre como un fenómeno más que subyacente. Ambos forman parte de la fragilización o vulnerabilidad indígena en México y Latinoamérica, pues conjuga situaciones de empobrecimiento, marginalización, estructuras de discriminación e inequidades de diverso rubro, heredadas desde la colonización, las cuales continúan amarradas a ella a través de los arreglos y las políticas del orden modelado desde el Estado-nación moderno.

El concepto de "fragilización o vulneración indígena" hace referencia al estado, condición o posición socioeconómica, política y cultural otorgada de forma histórica, coyuntural y estructuralmente a los pueblos indígenas en México y Latinoamérica. Es un that their exploration and comprehension take into account scenarios of survival and historical reproduction. That is, that they are oriented by considering the contradictions that occur between the imaginaries and the stereotypes that sustain indigenous ethnification and genderization. What is interesting is to point towards the mechanisms of ethnic otherness and the historical gender reinforcements influenced by western patriarchy and heterosexism. As Foucault (1977) emphasizes, de-essentializing what is naturalized requires noticing those emerging processes, even when these are judged as minuscule, insignificant and of low reach, and it is even fundamental to explore their apparent absence?

Processes of ethnification can be seen through the rereading of various sociological and anthropological contributions that have been made about indigenous peoples. For example, through pointing out the social, cultural, economic, political and legal conditions of indigenous peoples in Latin America, Peña, Cabedo and López (2002) contribute to identifying such a phenomenon as a historical product of complex constraints where genderization is discovered as another phenomenon that is more than underlying. They are both part of the indigenous fragilization or vulnerability in México and Latin America, for they conjugate situations of impoverishment, marginalization, structures of discrimination and inequities of various kinds, inherited from Colonial times, which continue to be tied to it through arrangements and policies of the order modelled by the modern State-nation.

The concept of "indigenous fragilization or vulnerability" refers to the state, condition or socioeconomic, political and cultural position granted in a historical, circumstantial and structural manner to indigenous peoples in México and Latin America. It is a phenomenon that begins and is made complex from colonization, as a historical moment of long duration, of terrible consequences; among them, the extinction of a great majority of native peoples as a result of genocide and their phagocytosis or assimilation. Thus, indigenous survival and reproduction has been made fragile as consequence of the emergence and consolidation of the West as hegemonic culture and power in the world.

The phenomena mentioned cannot be understood outside of conflict and negotiation ${ }^{10}$; they refer to the deterioration of indigenous power structures 
fenómeno que inicia y se complejiza a partir de la colonización, en tanto momento histórico de larga duración, de consecuencias nefastas; entre ellas, la extinción de una gran mayoría de pueblos originarios a causa del genocidio y de su fagocitación o asimilación. Así, la supervivencia y reproducción indígena ha sido fragilizada como consecuencia de la emergencia y la consolidación de occidente como cultura y poder hegemónico en el mundo.

Los fenómenos enunciados no pueden verse fuera de conflicto y negociación ${ }^{10}$; remiten al desmedro de las estructuras y relaciones de poder indígenas, de la cultura misma, de la subjetividad y subjetivación del sujeto originario a través de procesos radicalmente drásticos y explícitos de violencia. En la historia de los pueblos indígenas representan momentos álgidos y complejos que han marcado su actual etnicidad en constante resignificación ${ }^{11}$.

Esos procesos han permeado la subjetividad indígena, su organización y las relaciones y posiciones de las y los sujetos. Por ejemplo, durante la colonización se forjó al sujeto indígena desde el estereotipo del "bárbaro" o "salvaje", lo cual justificó su adoctrinamiento judeocristiano e incluso su exterminio. Posteriormente, a lo largo de los doscientos años de implantación del modelo de Estado nación moderno, el sujeto indígena ha sido sometido a un proceso educador sobre la ideología liberal, presumiblemente democrática. En la actualidad se encuentra bajo los influjos paradójicos de la globalización ${ }^{12}$.

En el caso de la generización, ésta se entiende como un proceso educativo complejo, subyacente a la etnicización, -o quizá sea al revés- implementado por instituciones occidentales que han buscado implantar el sistema patriarcal y heterosexista entre los pueblos indígenas. A través de este proceso se han delineado e impuesto los modelos de ser hombre y ser mujer como fundamentos de instituciones convencionales a esos sistemas, tales como la "familia" y la "comunidad" patriarcal en las que se ha legitimado el poder masculino como autoridad.

La mirada al interior y exterior de los pueblos indígenas, desde la perspectiva de género, plantea elevar las problemáticas de género como necesidades estratégicas de supervivencia y reproducción estratégica, al grado que se han reconocido los derechos étnicos de grupo. Por ello es necesario evidenciar cómo se reproducen y fortalecen las legitimaciones ideológicas y los sistemas simbólicos dualistas en los entramados and relations, of culture itself, of subjectivity and subjectivation of the native subject through radically drastic and explicit processes of violence. In the history of indigenous groups, they represent decisive and complex moments that have marked their current ethnicity in constant re-signification ${ }^{11}$.

These processes have permeated indigenous subjectivity, their organization and the relationships and positions of male and female subjects. For example, during colonization the indigenous subject was shaped from the stereotype of "barbarian" or "wild", which justified their Judeo-Christian indoctrination and even their extermination. Later, throughout the two hundred years of implantation of the modern State-nation model, the indigenous subject has been subdued by an educational process about liberal, presumably democratic, ideology. Currently, he/she is under the paradoxical influence of globalization ${ }^{12}$.

In the case of genderization, it is understood as a complex educational process, which underlies the ethnification -or perhaps it is the other way aroundimplemented by western institutions that have sought to implant the patriarchal and heterosexist system among indigenous peoples. Through this process, the models of being man and being woman have been drawn up and imposed, as fundaments of institutions that are conventional to these systems, such as the patriarchal "family" and "community" where the masculine power has been legitimized as authority.

The interior and exterior view of indigenous peoples, from the gender perspective, suggests elevating gender issues as strategic needs for survival and strategic reproduction, to the degree that the ethnic rights of the group have been recognized. Therefore, it is necessary to evidence how the ideological legitimations and dualist symbolic systems are reproduced and strengthened in indigenous structural frameworks, the manner in which they favor and reproduce inequities and gender discriminations, as well as the way in which they contribute to model "hegemonic masculinities" and to establish "masculine domination".

\section{DISCOURSES OF HEGEMONY, DOMINATION AND SUB-OTHERNESS IN STUDIES OF INDIGENOUS MASCULINITIES}
The discourses of hegemonic
(Connell, 1995) and masculine domination 
indígenas, la forma en que favorecen y reproducen inequidades y discriminaciones de género, así como la forma en que contribuyen a modelar "masculinidades hegemónicas" y establecer la "dominación masculina”.

\section{LOS DISCURSOS DE HEGEMONÍA, DOMINACIÓN Y SUBALTERIDAD EN LOS ESTUDIOS DE LAS MASCULINIDADES INDÍGENAS}

Los discursos de la masculinidad hegemónica (Connell, 1995) y la dominación masculina (Bourdieu, 2007) tienen amplia utilidad teórica para develar las influencias y represiones patriarcales y heterosexistas sobre el sujeto generizado y diverso, contando con elementos que permiten visibilizar los vínculos existentes entre el orden occidental y el indígena.

El concepto de masculinidad hegemónica de Connell (1995:61) expone que es necesario ir más allá del reconocimiento de que la masculinidad es diversa y que en esa diversidad existe una "política de género en la masculinidad". Textualmente indica que "...debemos reconocer las relaciones entre diferentes formas de masculinidad: relaciones de alianza, dominio y subordinación. Estas relaciones se construyen a través de prácticas que excluyen e incluyen, que intimidan, explotan, etcétera.”. Tal política de género de la masculinidad está fuertemente ligada a intereses de sistemas culturales, económicos y políticos. Por ejemplo, en Occidente los sistemas de género se encuentran ligados a intereses económicos capitalistas, doctrina judeocristiana e ideología liberal y neoliberal, en tanto que el discurso bourdiano sobre la "dominación masculina" plantea que la "somatización de las relaciones sociales dominantes" se dan "solo a cambio y al término de un formidable trabajo colectivo de socialización difusa y continua (donde) ${ }^{13}$ las identidades distintivas que instituye el arbitrario cultural se encarnan en unos hábitos claramente diferentes de acuerdo con el principio de división dominante y capaces de percibir al mundo con ese principio" (Bourdieu, 2007:38).

El concepto neo marxista de "dominación" utilizado por Bourdieu (2007:26, 28) y aplicado a las relaciones de género destaca que existe una forma de masculinidad que se erige como poder simbólico. Al respecto, el autor citado alude que puede advertirse: "cuando los dominados aplican a lo que les domina unos esquemas que son el producto de la dominación... cuando sus pensamientos y sus percepciones
(Bourdieu, 2007) have a broad theoretical utility to reveal the patriarchal and heterosexist influences and repressions on the genderized and diverse subject, having elements that allow making visible the existing correlations between the western and the indigenous order.

Connell's concept of hegemonic masculinity (1995:61) exposes that it is necessary to move beyond the recognition that masculinity is diverse and that in such diversity there is a "gender policy in masculinity". Textually, he states that "...we must recognize the relationships between different forms of masculinity: relationships of alliance, dominance and subordination. These relationships are constructed through practices that exclude and include, that intimidate, exploit, etc." Such a gender policy of masculinity is strongly connected to interests in cultural, economic and political systems. For example, in the West, gender systems are linked to capitalist economic interests, Judeo-Christian doctrine, and liberal and neoliberal ideology; at the same time, Bourdieu's discourse about "masculine domination" suggests that the "somatization of dominating social relationships" occurs "only in exchange for and at the end of enormous collective work for diffuse and continuous socialization (where) ${ }^{13}$ the distinctive identities that cultural arbitrariness institutes are embodied into clearly different habits according to the principle of dominating division and capable of perceiving the world with this principle" (Bourdieu, 2007:38).

The neo-Marxist concept of "domination" used by Bourdieu $(2007: 26,28)$ and applied to gender relationships highlights that there is a form of masculinity that is erected as symbolic power. In this regard, the author mentions that it can be seen: "when those dominated apply to those who dominate them certain schemes that are the product of domination... when their thoughts and perceptions are structured according to the very structures of the domination relationship that has been imposed, their acts of knowledge are, inevitably, acts of recognition, of submission".

Therefore, "masculine domination" is conceived as an expression of genderized power and legitimized as authority, where the "masculine principle appears as the measure of everything", establishing an order between those dominated and the dominating in the concert of gender, as "an arbitrary social construction 
están estructurados de acuerdo con las propias estructuras de la relación de dominación que se les ha impuesto, sus actos de conocimiento son, inevitablemente, unos actos de reconocimiento, de sumisión".

Por tanto, la "dominación masculina" se concibe como una expresión de poder generizado y legitimado como autoridad, donde el "principio masculino aparece como la medida del todo", estableciendo un orden entre dominados y dominadores en el concierto de género, como "una construcción social arbitraria de lo biológico y, en especial, del cuerpo masculino y femenino, de sus costumbres y de sus funciones, en particular de la reproducción biológica, que proporciona un fundamento aparentemente natural a la visión androcéntrica de la división de la actividad y de la división sexual del trabajo y, a partir de ahí, de todo el cosmos. La fuerza especial de la sociodicea masculina procede de que acumula dos operaciones: legitima una relación de dominación en una naturaleza biológica que es en sí misma una construcción social naturalizada" (op cit: 37 ).

Los orígenes de la dominación masculina en Occidente se encuentra unido y reforzado durante y a través del sistema económico dominante, inaugurado desde la emergencia de la sociedad moderna (Seidler, 2000) e industrial (Mosse, 2000), (re)creando un orden donde la subjetividad del sujeto gira en torno a una tendencia economicista, dirigido a dominarse así, a los demás y al medio ambiente ${ }^{14}$ desde una racionalidad de competencia, dominio, subordinación y exclusión.

La cuestión antes planteada marca la necesidad de contemplar la diversidad de situaciones que condicionan la subjetividad masculina y los ejes comunes que la identifican con la hegemonía y la subalteridad. Al respecto, Hernández (1998:218) señala que en el caso de los pueblos indígenas y afroamericanos que perviven en Latinoamérica se reproduce en su interior un modelo de masculinidad hegemónica que define como "identidades étnicas subordinadas" e "identidades masculinas hegemónicas" de consecuencias diversas, en las que señala las concernientes a las mujeres. Sobre la primera señala que: "La autoadscripción a un grupo culturalmente discriminado conduce a la conformación de identidades étnicas subordinadas, según el nivel o estadio de conciencia de pertenencia o rechazo por el que cada individuo o grupo social transita". En el caso de la segunda apunta que: "existe una jerarquización socialmente aceptada de las decisiones de los hombres, e incluso, cierta permisividad of the biological and, specially, of the masculine and feminine body, its customs and functions, in particular of biological reproduction, which provides an apparently natural foundation to the androcentric vision of the division of activity and the sexual division of labor and, from this, of the whole cosmos. The special force of the masculine social odyssey is the result of it accumulating two operations: legitimizing a relationship of domination in a biological nature that is in itself a naturalized social construction" (op cit: 37).

The origins of masculine domination in the West are united to and reinforced during and through the dominating economic system, inaugurated from the emergency of modern (Seidler, 2000) and industrial (Mosse, 2000) society, (re)creating an order where subjectivity of the subject revolves around an economicist tendency, directed at dominating him/herself, others and the environment ${ }^{14}$ from a rationality of competition, dominion, subordination and exclusion.

The question set out before marks the need to contemplate the diversity of situations that condition masculine subjectivity and the common axes that identify it with hegemony and sub-otherness. In this regard, Hernández (1998:218) points out that in the case of indigenous and African-American peoples who live on in Latin America, a model of hegemonic masculinity is reproduced inside them, which he defines as "subordinate ethnic identities" and "hegemonic masculine identities" of various consequences, where those concerning women are pointed out. About the first, he mentions that: "The self-ascription to a culturally discriminated group leads to the conformation of subordinate ethnic identities, based on the level or state of consciousness of belonging or rejection by which each individual or social group is moving". In the case of the second, he states that: "there is a socially accepted hierarchy of the decisions of men, and even, some cultural permissiveness regarding arbitrary masculine behaviors. The legitimation of man's authority over woman's, leads to the cultural construction of hegemonic masculine identities". The arguments presented reveal that the condition and position of women are recurrently identified by strong devaluations and diverse consequences linked to the exercise of masculine power, with asymmetries, inequalities and violence being some of its characteristics. 
cultural de comportamientos masculinos arbitrarios. La legitimación de la autoridad del hombre por encima de la mujer conduce a la construcción cultural de identidades masculinas hegemónicas". Los planteamientos aludidos develan que la condición y posición de las mujeres está recurrentemente identificado por fuertes desvaloraciones y diversas consecuencias vinculadas con el ejercicio del poder masculino, siendo las asimetrías, las desigualdades y las violencias unas de sus características.

\section{Conclusiones}

\section{Propuestas sobre la exploración investigativa de las masculinidades indígenas}

Como se ha discutido a lo largo de este trabajo, tanto en las sociedades modernas (Cortés, 2004; Mosse, 2000) como en las indígenas (Mott, 2006) existe una alta susceptibilidad a los ordenamientos de género orientados desde el patriarcado, el heterosexismo y el capitalismo. Sin embargo, en el caso de los estudios de las masculinidades indígenas se requiere ser particularizados, además de revisar sus trascendencias tanto para las mujeres, los hombres y las otras identidades genéricas reprimidas, como para el medio ambiente.

Sin intentar disminuir la situación problemática que viven las mujeres indígenas, se necesita reconocer y evidenciar que los hombres también viven cuestiones graves que necesitan discutirse y atenderse. Algunos estudios de las masculinidades indígenas han develado que los hombres asumen mandatos como los de la proveeduría y las jefaturas domésticas y comunitarias, entre otras, bajo las condiciones de precariedad de recursos como el trabajo o de baja productividad de sus unidades productivas, cuestión que dificulta cumplir dichos mandatos y, por tanto, de consecuencias para sí y para con quienes cohabita y convive.

Sin embargo, los estudios de género de los hombres se enfrentan a diversas dificultades, entre ellas a la necesidad de superar la idea generalizada que concibe a los varones como principales beneficiarios del orden patriarcal y heterosexista (Connell, 1995). Esos estudios están obligados, a través de la perspectiva de género, a visibilizar las trascendencias de ese orden en los "hombres" (Izquierdo, 2007) y verlos como sujetos que lo vivencian de manera diferenciada a las mujeres. Como apunta Jiménez (2002:12):

\section{Conclusions}

\section{Proposals about the investigative exploration of indigenous masculinities}

As has been discussed throughout this paper, both in modern societies (Cortés, 2004; Mosse, 2000) an in indigenous ones (Mott, 2006) there is a high susceptibility to gender ordering directed from patriarchy, heterosexism and capitalism. However, in the case of indigenous masculinities studies, they should be particularized, in addition to having their transcendence revised, both for women, men and other repressed gender identities, and for the environment.

Without attempting to diminish the problematic situation that indigenous women experience, it is necessary to recognize and make evident that men also experience serious issues that need to be discussed and addressed. Some studies of indigenous masculinities have revealed that men take on mandates such as providing and heading households and communities, among others, under conditions of precariousness of resources such as work or of low productivity of their productive units, an issue that makes it difficult to fulfill those mandates and, therefore, with consequences for themselves and for those with whom he cohabits and coexists.

However, gender studies about men face diverse difficulties, among them the need to surpass the generalized idea that conceives males as principal beneficiaries of the patriarchal and heterosexist order (Connell, 1995). Those studies are forced, through gender perspective, to make visible the transcendences of that order in "men" (Izquierdo, 2007) and to perceive them as subjects who experience it in a manner differentiated from women. As Jiménez (2002:12) suggests: “...there is increasingly a consensus about gender being a relational term, which has both to do with men and with women, and, in this sense, it is important to give voice to males and to try to understand their reality and lifestyle from their own perspective".

The risks of considering that men are the principal beneficiaries of the patriarchal and heterosexist order are, among others, that they are essentialized as violent subjects, reckless, machista ${ }^{15}$ and other assignations, limiting the application of broad and plural perspectives in their comprehension (Rivas, 
“...cada vez más hay un consenso acerca de que género es un término relacional, que tiene que ver tanto con los hombres como con las mujeres y que, en este sentido, resulta relevante dar voz a los varones y tratar de comprender su realidad y forma de vivir desde su propia perspectiva”.

Los riesgos de considerar que los hombres son los principales beneficiarios del orden patriarcal y heterosexista son, entre otros, que los esencializan como sujetos violentos, temerarios, machistas ${ }^{15}$ y demás adjudicaciones, lo cual limita la aplicación de perspectivas amplias y plurales en su comprensión ( $\mathrm{Ri}$ vas, 2006). Por ejemplo, Núñez (2006:51) señala que "Muchos varones son oprimidos, discriminados por otros hombres y mujeres, y privados no solo de los beneficios simbólicos como hombres, sino de su dignidad humana. Los discursos racistas, clasistas, homofóbicos e integristas de género sirven para clasificar a los varones según su poder simbólico. Los discursos dominantes de la hombría muchas veces niegan la identidad de hombres a muchos machos humanos". Las ideas expuestas demandan una mayor comprensión del sujeto masculinizado desde el patriarcado y heterosexismo, pues continuar negando la pluralidad de la masculinidad y el ser hombre o, como señala Connell (1995), dejar de lado la existencia de las políticas masculinas, es continuar sosteniendo la criminalización de los hombres, cuestión que se empeora en el caso de los varones indígenas ${ }^{16}$.

Durante y después de la colonización los hombres indígenas han sido, generalmente, sujetos de criminalización, mas no de derecho, lo que la mayoría de las veces es una expresión discriminatoria y racializante. Como ilustra Martínez de Bringas (2003:10): "Desde ahora, el único sujeto posible de derecho será el individuo masculinamente blanco, excelsamente individual y libérrimamente autónomo, un sujeto a quien espanta la coloración y cromaticidad de las pieles".

Por otra parte, la vigencia del dualismo de género en gran parte de los estudios de las masculinidades, incluso en de contextos indígenas, ha condicionado que el sujeto de estudio se centre en perfiles de hombres y mujeres convencionales al heterosexismo. Por tanto, una pregunta obligada a ser abordada en los estudios de género de los hombres indígenas sería: ¿qué pasa con las diversidades sexuales indígenas discrepantes del orden heterosexista? Al respecto, Núñez (2006) señala que los diversos significados y contenidos de género que constriñen el ser "hombre" y "mujer" se dan en
2006). For example, Núñez (2006:51) suggests that: "Many males are oppressed, discriminated against by other men and women, and deprived not only of symbolic benefits as men, but of their human dignity. The racist, classist, homophobic and gender integrist discourses are useful to classify males according to their symbolic power. The dominating discourses about manliness many times deny the identity of men to many human males". The ideas exposed demand a greater understanding of the subject that is masculinized from patriarchy and heterosexism, since continuing to deny the plurality of masculinity and of being a man, or, as Connell (1995) states, leaving aside the existence of masculine policies is continuing to support the criminalization of men, a matter that is worsened in the case of indigenous males. ${ }^{16}$

During and after the colonization of indigenous men, they have been, generally, subjects of criminalization although not of the rule of law, which most times is a discriminatory and racializing expression. As Martínez de Bringas (2003:10) illustrates: "From now on, the only possible subject of the rule of law will be the white masculine individual, sublimely individual and freely autonomous, a subject who is afraid of color and coloring of skins".

On the other hand, the validity of gender dualism in large part of masculinities studies, including indigenous contexts, has conditioned for the study subject to center on profiles of men and women that are conventional to heterosexism. Therefore, a mandatory question to be tackled in gender studies of indigenous men would be: What happens to indigenous sexual diversities divergent from the heterosexist order? In this regard, Núñez (2006) states that the various meanings and gender contents that constrain being "man" and "woman" occur in terms of what is constructed, signified and exercised as heterosexual, and their limits are marked by homophobia and homo-eroticism. This author, as well as Palma (2006), among others, has opened windows for discussion and reflection about these situations under indigenous contexts, also documenting indigenous gender diversity. One of the most explored cases is that of muxes in some Zapotec towns in Tehuantepec, Oaxaca (Miano, 1998). Other cases that are beginning to be studied are those referring to prostitution of young indigenous migrants in Mexican cities or border cities 
términos de lo construido, significado y ejercitado como heterosexual y sus delimitaciones marcadas por la homofobia y el homo-erotismo. El autor antes citado, así como Palma (2006), entre otros(as), han abierto ventanas de discusión y reflexión sobre estas situaciones en contextos indígenas, documentando además la diversidad de género indígena. Uno de los casos de mayor exploración es el de los muxes en algunos pueblos zapotecas de Tehuantepec, Oaxaca (Miano, 1998). Otros casos que empiezan a estudiarse son los referidos a la prostitución de jóvenes indígenas migrantes en las ciudades mexicanas o las situadas en las fronteras de México en el sur y con los EE. UU. En este marco cabe señalar los trabajos de Núñez (2009) sobre el problema del VIH-Sida en migrantes rarámuri. En general, el imaginario que se tiene sobre los pueblos indígenas reproduce ideas consideradas tradicionales y sostenidas en la homofobia, las cuales también son poco o nada estudiadas.

Además de los derroteros apuntados, la agenda de los estudios de las masculinidades indígenas puede estar más completa al contemplar abordajes sobre sus trascendencias en el medio ambiente. Atender esta demanda, siguiendo las propuestas epistémicas de Amorós (2000), conlleva un gran reto pues los estudios de las masculinidades no solo requieren superar los sesgos etnocéntricos y androcéntricos, sino también los antropocéntricos. $\mathrm{Al}$ respecto, son pocos los estudios que vinculan a la masculinidad con el medio ambiente; uno de ellos es el expuesto por Pérez (2003).

La exploración de las masculinidades indígenas y su relación con el medio ambiente requieren considerar la forma en que éstas se involucran en los modos de producción, distribución, consumo y residualización, procesos centrales de la sobrevivencia y reproducción de los pueblos indígenas. Es decir, cabe averiguar cómo las construcciones y prácticas de lo masculino permean la significación, el uso, el manejo y el control de los recursos, además del cómo ello se ve reflejado en el medio ambiente o en la generación y el fortalecimiento del poder y el prestigio o estatus entre hombres y mujeres.

El estudio de la relación entre masculinidad(es) y medio ambiente pueden guiarse en dos sentidos: sobre el contexto de sus relaciones con Occidente o hacia su interior. En el primero se requiere partir de escudrinar los mecanismos que favorecen la continuidad del expolio de los patrimonios tangibles e intangibles indígenas por parte de Occidente. A pesar de que este fenómeno ha sido sistemático, desde la in southern México, and at the US border. In this framework, the studies by Núnez (2009) about the HIV-AIDS problem in Rarámuri migrants should be highlighted. In general, the imaginary present about indigenous peoples reproduces ideas considered traditional and sustained on homophobia, which are also scarcely studied or not at all.

In addition to the paths pointed out, the agenda of indigenous masculinities studies could be more complete when contemplating approaches about their transcendences in the environment. Addressing this demand, following the epistemic proposals by Amorós (2000), entails a great challenge because masculinities studies not only require overcoming ethnocentric and androcentric biases, but also anthropocentric. In this regard, there are few studies that correlate masculinity with the environment; one of them is by Pérez (2003).

Exploring indigenous masculinities and their relationship with the environment requires considering the way in which these are involved in the modes of production, distribution, consumption and residualization, central processes for survival and reproduction of indigenous peoples. That is, it is worth studying how the constructions and practices of what is masculine permeate the signification, the use, the management and the control of resources, and also how this is reflected in the environment or in the generation and strengthening of power and prestige or status among men and women.

The study of the relationship between masculinity(ies) and the environment could be guided in two directions: on the context of their relations with the West or towards their interior. In the first, it is required to begin by scrutinizing the mechanisms that favor the continuity of the plundering of indigenous tangible and intangible patrimonies by the West. Although this phenomenon has been systematic, since the colonization and until today, indigenous peoples in México and Latin America still have important bastions of biodiversity, which are still a cause for discord, although their deterioration is increasingly more evident. This situation becomes complex and tense, which is why some meaningful fields for research about masculinities can be those situated in the gaps of intercultural, territorial, patrimonial and gender conflicts.

Making this assessment suggests understanding that the signification, use, management and control 
colonización hasta el día de hoy los pueblos indígenas en México y Latinoamérica aun cuentan con reductos importantes de biodiversidad, mismos que siguen siendo motivo de discordia, aunque su deterioro es cada vez más evidente. Esta situación se torna compleja y se tensa, por lo que algunos campos significativos de investigación sobre las masculinidades pueden ser las situadas en los intersticios de los conflictos interculturales, territoriales, patrimoniales y de género.

Hacer esta apreciación propone entender que la significación, uso, manejo y control de los recursos del medio ambiente entre los pueblos indígenas se encuentra seriamente afectada por la internalización del modo de producción capitalista, el cual ha caminado a la par de la emergencia y la consolidación del orden moderno e industrial. Por ello, los estudios de las masculinidades indígenas, requieren considerar este escenario dado que podrían revelar cómo la continuidad de la socialización occidental favorece el cultivo de una manera convencional de masculinidad a ese orden, donde se privilegia la ciudadanía y el patriotismo nacionalista (Mosse, 2000; Cortés, 2004), el patriarcado y el heterosexismo (Guasch, 2000), así como la neoconfiguración del homo economicus (Mellor, 2006), a la par del advenimiento neoliberal.

El problema del deterioro ambiental indígena es redimensionado bajo las condicionantes de la desigualdad étnica que estos pueblos viven al interior de Estados-nación como México y Latinoamérica, donde existen políticas discriminatorias de bajo reconocimiento multicultural, de efectos directos en los reconocimientos territoriales y de alta susceptibilidad al expolio. Por ello, un acercamiento a las realidades indígenas ambientales desde la perspectiva de género es un asunto de suma importancia.

Partiendo del contexto interior respecto al giro de los estudios de las masculinidades y el medio ambiente, se requiere explorar y cuestionar aquellos arreglos socioculturales y políticos catalogados como cosmovisión, usos y costumbres, entre otras formas en que se construyen y ejercitan las fidelidades étnicas y los compromisos como comunidades morales y la forma en que significan y median el acceso, uso, manejo y control de los recursos de sus espacios medioambientales. El abordaje de estos elementos que conforman los escenarios de la comunalidad indígena abre posibilidades en la comprensión de las subjetividades, las posiciones y las condiciones de género de hombres, mujeres y de otras identidades genéricas existentes, of resources from the environment among indigenous peoples is gravely affected by the internalization of the capitalist mode of production, which has changed along with the emergence and consolidation of the modern and industrial order. Therefore, the studies on indigenous masculinities require considering this scenario, since they could reveal how the continuation of Western socialization favors cultivating a manner of masculinity conventional to that order, where the nationalist citizenship and patriotism (Mosse, 2000; Cortés, 2004), the patriarchy and heterosexism (Guasch, 2000), as well as the neo-configuration of the homo economicus (Mellor, 2006), are privileged together with the neoliberal advent.

The problem of indigenous environmental deterioration is streamlined under the determinants of the ethnic inequality that these peoples experience inside State-nations such as México and Latin America, where there are discriminatory policies of low multicultural recognition, of direct effects on territorial recognition, and of high susceptibility to plundering. Thus, an approach to environmental indigenous realities from the gender perspective is a matter of utmost importance.

Starting from the interior context with regard to the change in studies of masculinities and the environment, it is required to explore and question the sociocultural and political arrangements catalogued as worldview and customs, among other forms in which ethnic fidelities and commitments as moral communities are constructed and exercised, and the control of resources in their environmental spaces. Approaching these elements that make up the scenarios of indigenous communities opens up possibilities in the comprehension of subjectivities, positions and conditions of gender in men, women and other existing gender identities, dissident or emerging, with regard to their relationships and impacts on the environment.

- End of the English version -

disidentes o emergentes, respecto a sus relaciones e impactos en el medio ambiente.

\section{Notas}

${ }^{1}$ El concepto de "fragilización" apunta a expresar una visión problematizada del término neutralizado de 
"fragilidad". Plantea que la fragilidad o vulnerabilidad de los pueblos indígenas contemporáneos es un fenómeno con causas históricas donde se identifican complejos de marginalización, empobrecimiento y discriminación étnica y de género. $u{ }^{1}$ The concept of "fragilization" serves to express an antagonized vision of the neutral term "fragility." It proposes that the fragility or vulnerability of contemporary indigenous peoples is a phenomenon with historical causes where certain complexes of marginalization, impoverishmentand ethnicand gender discrimination can be identified. - The concept of "fragilization" serves to express an antagonized vision of the neutral term "fragility." It proposes that the fragility or vulnerability of contemporary indigenous peoples is a phenomenon with historical causes where certain complexes of marginalization, impoverishment and ethnic and gender discrimination can be identified. ${ }^{2} \mathrm{El}$ derecho internacional ha reconocido que la marginalización de los pueblos indígenas en el continente americano está en función de la falta de reconocimientos y de respeto de sus derechos. Una discusión en esta línea ha sido expuesta por Martínez de Bringas (2003:9), quien cita al respecto: "En la topografía de las identidades modernas, los pueblos indígenas no han existido. Por tanto, lo que no ha existido no puede ser reconocido y lo que no puede ser objeto de reconocimiento carece, en última instancia, de identidad". Sin embargo, llevando esta observación al interior de los pueblos indígenas existen otros sujetos sin reconocimiento, sin valoración, sin identidad, tales como las mujeres y aquellos cuya subjetividad no converge con los cánones patriarcales y heterosexistas. $\bullet$ International law has recognized that marginalization of indigenous peoples in the American continent is due to a lack of recognition and respect of their rights. Drawing on this, a discussion has been brought forth by Martínez de Bringas (2003: 9), who writes: "In the topography of modern identities, indigenous peoples have not existed. Thus, what has not existed cannot be recognized and what cannot be an object of recognition is lacking, ultimately, in identity." However, extending this observation inside indigenous peoples, there are other subjects without recognition, without valuation, and without identity, such as women or those whose subjectivity does not converge with the patriarchal and heterosexist canons.
${ }^{3} \mathrm{La}$ ciencia en Occidente depura lo que es un conocimiento válido de lo que no lo es, a través de principios cartesianos fundados en orientaciones antropocéntricas, etnocéntricas y excesivamente androcéntricas (Amorós, 2000). A lo largo de su emergencia y hegemonía como medio legitimado de producir conocimientos, se ha convertido en uno de los baluartes y fortaleza de la masculinidad hegemónica. Al respecto, Seidler (2000: 40) señala que: "Las concepciones del conocimiento han solido vincularse inconscientemente con ciertas ideas de masculinidad desde que las revoluciones científicas del siglo XVII se concibieron como una nueva filosofía masculina”.

Western science clarifies between what is considered valid knowledge and what is not, through the use of Cartesian principles founded on anthropocentric, ethnocentric and excessively androcentric stances (Amorós, 2000). Throughout its emergence and predominance as the legitimate means of knowledge production, it has become one of the bastions and strongholds of hegemonic masculinity. To that respect, Seidler (2000: 40) claims that: "The conceptions of knowledge have tended to relate unconsciously to certain ideas of masculinity ever since the scientific revolutions of the $17^{\text {th }}$ Century were conceived as a new masculine philosophy."

${ }^{4} \mathrm{La}$ propuesta de una epistemología desde el Sur, según De Sousa (2009:12) es: “...la búsqueda de conocimientos y de criterios devalidezdel conocimiento que otorguen visibilidad a las prácticas cognitivas de las clases, de los pueblos y de los grupos sociales que han sido históricamente victimizados, explotados y oprimidos por el colonialismo y capitalismo globales". Es entonces el "Sur", como él mismo explica, "una metáfora del sufrimiento humano", disyuntiva que plantea todo tipo de opresión como las de género y etnia, que requieren ser problematizados como sujetos de estudio y de política. The proposal of an epistemology of the South origin, according to De Sousa (2009: 12) is: “...the search for knowledge and validity criteria of knowledge that provide visibility to the cognitive practices of the classes, the peoples and the social groups that have been historically victimized, exploited and oppressed by global colonialism and capitalism. The "South" is then, as he explains, "a metaphor of human suffering," a predicament derived that sets out all kinds of oppression like that of gender and ethnicity, which must be appraised as subjects for study and of policy. 
${ }^{5}$ Dussel (2005) denomina a este fenómeno como "Despliegue del Sistema-mundo occidental", el cual se da a partir de que la Europa del Siglo XIV-XV se recompone territorialmente, en cuyo contexto el reino de Castilla se erigió como la génesis española a través de la expulsión musulmana de la Península Ibérica. Este hecho conjugó el supuesto "descubrimiento" del nuevo continente y su colonización.

Dussel (2005) denominates this phenomenon as the "Deployment of the western world-system", which takes place after $14^{\text {th }}-15^{\text {th }}$ Century Europe was territorially recomposed and in whose context the reign of Castilla was erected as the Spanish genesis through the Muslim expulsion from the Iberian Peninsula. This fact combined the alleged "discovery" of the new continent and its colonization.

${ }^{6}$ Los conceptos de resiliencia y resistencia indígena aluden a la recuperación, revaloración o resignificación de saberes diversos, maneras de pensar y concebir al mundo. No se plantean en el sentido de alimentar la supuesta inmutabilidad o esencialismo indígena, sino atisbar la complejidad de procesos que alimentan las etnicidad, fidelidades o pertenencias a lo considerado como comunidad indígena u originaria en la que están en juego las subjetividades e intereses de género. The concepts of indigenous resilience and resistance refer to the recuperation, revaluation or re-signification of various wisdoms, ways of thinking and conceiving the world. They are not suggested in the sense of feeding the supposed indigenous immutability or essentialism, but rather to discern the complexity of processes that feed ethnicity, fidelity or sense of belonging in what is considered an indigenous or native community where gender subjectivities and interests are at play.

${ }^{7}$ Por ejemplo, Pérez Nasser (2011) alude a los procesos de transformación generacional sobre significados y prácticas de la masculinidad y el ser hombres indígenas nahuas de la Sierra Norte de Puebla, México.

For example, Pérez Nasser (2011) refers to processes of generational transformation of meanings and practices of masculinity and what it entails to be indigenous Nahua men in the Sierra Norte of Puebla, México.

${ }^{8}$ Relaciones de poder, producción y catexis son tres dimensiones del modelo que propone Connell (1995:112-113) para reflexionar sobre la construcción social de la masculinidad. Las relaciones de poder desenmascaran la supuesta total subordinación de las mujeres como producto de dominación masculina.
Sin embargo, el autor aludido define al patriarcado en función de la existencia de relaciones de subordinación femenina y dominio masculino. Las relaciones de producción las enfatiza en función de la división y reconocimiento del trabajo, valoración moral y retribución, sus consecuencias económicas, la distribución y acumulación de ganancias, el control de los procesos productivos y distributivos, etcétera, todas ellas permeadas por preponderancia masculina sobre la femenina. En el caso de la catexis, se refiere al ámbito de las emociones y sentimientos tales como el deseo y prácticas sexuales, que en contexto heterosexista y patriarcal son prioritariamente reproductivas y represivas de otros sentimientos, placeres y deseos. Cabe aclarar que su modelo está dirigido a explicar la masculinidad en la cultura occidental, haciendo referencia sólo a algunos países, que él cree son representativos de ese orden, en el que además, abre la ventana de ver la acción histórica feminista, lo cual, hace ver al modelo aludido como un proceso epistémico, teórico y metodológico en construcción. Relations of power, production, and cathexis are three dimensions of the model proposed by Connell (1995: 112-113) to reflect upon the social construction of masculinity. Power relations unmask the supposed total subordination of women as a product of masculine domination. The cited author, however, defines patriarchy in function of the existence of relationships of feminine subordination and male dominion. Production relations are emphasized in function of the division and recognition of labor, the moral valuation and retribution, their economic consequences, the distribution and accumulation of earnings, the control of productive and distributive processes, etcetera, all permeated by a masculine preponderance over the feminine. In the case of cathexis, he refers to the sphere of emotions and feelings like desire and sexual practices which in a heterosexist and patriarchal context are primarily reproductive and repressive of other feelings, pleasures and desires. It is worth clarifying that his model is directed at explaining masculinity in western culture, referring to only certain countries that he believes are representative of that order. $\mathrm{He}$ also opens a window for viewing historical feminist action that allows the aforementioned model to be seen as an epistemic, theoretical and methodological process under construction.

${ }^{9}$ Un ejercicio desde el discurso foucaultiano de la genealogía es el realizado por Díaz (2013) y en él se 
exponen los momentos contextuales desde la colonización hasta nuestros días, en los que se ha significado la masculinidad indígena Xi'oi-pame de San Luis Potosí, México. Díaz (2013) carried out an exercise in the Foucaultian discourse on genealogy, where contextual moments are illustrated from colonialism up until the present day, in which the Xi'oi-pame indigenous masculinity in San Luis Potosí, México, has been signified.

${ }^{10}$ Para una mayor comprensión sobre los procesos conflictivos de la etnicidad de los Pueblos indígenas en México y Latinoamérica, puede recurrirse las lecturas clásicas de García Canclini (1989), Geertz (1987), entre otros. For a greater understanding of the conflictive processes of ethnicity in the indigenous peoples of México and Latin America, one can refer to the classic literature of García Canclini (1989), and Geertz (1987), among others.

${ }^{11}$ La resignificación de la etnicidad contemporánea de los Pueblos indígenas, interpretada con ayuda del discurso foucaultiano de la genealogía (Foucault, 1977), puede entenderse como el conjunto de contenidos simbólicos emergentes a partir de las socializaciones occidentales y las resistencias de las ancestralidades indígenas. The re-signification of contemporary ethnicity of indigenous peoples, interpreted with the aid of the Foucaultian discourse on genealogy (Foucault, 1997), can be understood as the combining of emergent symbolic content following western socialization and indigenous ancestral resistance.

${ }^{12}$ Las discusiones de Turner (1999) en torno a la posición y condición de los pueblos indígenas en el contexto de la globalización evidencian que esos fenómenos continúan haciéndose presentes. Turner's (1999) discussion in regards to the position and condition of indigenous peoples in the context of globalization demonstrates that those phenomena continue in their presence.

${ }^{13}$ Nota puesta sobre el original. $\downarrow$ Note placed over original.

${ }^{14}$ Martínez (2000) señala que el problema del deterioro ambiental afecta de manera diferenciada a hombres y mujeres indígenas, lo que conlleva a plantear exploraciones sobre los vínculos de la masculinidad hegemónica con el medio ambiente. $\bullet$ Martínez (2002) asserts that the problem of environmental deterioration affects indigenous men and women differentially, which leads to suggesting explorations of the correlations between hegemonic masculinity and the environment.
${ }^{15}$ El uso del concepto del "machismo" y su persistencia en el imaginario cotidiano revela un perfil cultural generalizado de ser "hombre" dentro de las culturas nacionales (Gutmann, 1998; Fuller, 1998). Bajo este imaginario y la prevalencia de una identidad nacional se esconden las diferencias y desigualdades masculinas. Páramo (2005:227) asume que la sociedad mexicana se sienta sobre una "cultura machista", la cual se encuentra en proceso de transformación debido a supuestos procesos emergentes y a las diferenciaciones de dicha "cultura machista" en la diversidad de la geografía mexicana, la economía, la educación y la participación de las mujeres en el mercado laboral, etcétera. The use of the concept of "machismo" and its persistence in everyday collective imaginary reveals a generalized cultural profile of being a "man" in the national cultures (Gutmann, 1998; Fuller, 1998). Under this collective imaginary and the prevalence of a national identity hide masculine differences and inequalities. Páramo (2005: 227) assumes that Mexican society is cemented upon a "machista culture" that is currently under a transformation process due to alleged emergent processes and differentiations of said "machista culture" in the diversity of Mexican geography, economy, education, and women's participation in the free market, etcetera.

${ }^{16}$ En el periódico La Jornada (2012) se anunció que en México había más de ocho mil hombres indígenas en las cárceles mexicanas, quienes han sufrido diversos abusos y violaciones a sus derechos humanos, vinculados a deficiencias en los procesos de justicia y a la carencia de defensores e intérpretes de idioma originarios. Esta situación muestra por una parte las vigentes discriminaciones étnicas y, por otra, la criminalización de los hombres. $\bullet$ It was announced in La Jornada newspaper (2012) that there were more than eight thousand indigenous men in Mexican jails who had suffered various forms of abuse and violations of their human rights related to deficiencies in judiciary processes and a lack of defense counsels and native language interpreters. This situation demonstrates, on the one hand, the prevailing ethnic discrimination, and on the other, the criminalization of men.

\section{Literatura Citada}

Amorós, Celia. 2000. Feminismo y filosofía. Síntesis. España. Bourdieu, Pierre. 2007. La dominación masculina. Anagrama. Colección argumentos. Barcelona, España.

Connell, R.W. 1995. Masculinidades. U. de Sydney. (Versión en español). PUEG. UNAM. México. 
Cortés, José Miguel G. 2004. Hombres de mármol. Códigos de representación y estrategias de poder de la masculinidad. Egales. Barcelona. España.

De Sousa Santos, Boaventura. 2009. Una epistemología del Sur: la reinvensión del conocimiento y la emancipación social. Siglo XXI, Clacso. México.

Díaz Cervantes, Rufino. 2012. Etnia, género y migración en la (re)significación masculina y sobrevivencia Xi'oi-pane. Tesis de Doctorado. Universidad de Deusto, País Vasco. España.

De Sousa Santos, Boaventura. 2013. Genealogía de la masculinidad indígena Xi'oi-pame. In: Juan Carlos Ramírez Rodríguez y José Carlos Cervantes Ríos (coord.) Los hombres en México, veredas recorridas y por andar. Una mirada a los estudios de género de los hombres, las masculinidades. Centro Universitario de Ciencias Económicas Administrativas; Academia Mexicana de Estudios de Género de los Hombres, A.C. México. pp: 153-175.

De Sousa Santos, Boaventura. 2014. Los estudios de las masculinidades y el activismo de grupos de hombres, sus contribuciones al empoderamiento de las mujeres. Revisión y perspectivas en México y Latinoamérica. Ponencia, X Encuentro Nacional sobre Empoderamiento Femenino, UAEH. Pachuca, México.

Dussel Ambrosini, Enrique. 2005. Europa, modernidad y eurocentrismo. Paideia. Mayo-junio-julio. No. 8- Año 2, Vol. 2. UAEM, III, UG. México. pp: 12-19.

Eng, David L. 2008. Raza y masculinidad. In: Àngels Carabí y Joseph M. Armengol (eds). ICARIA. Barcelona, España. pp: 95-110.

Ferrándiz Martín, Francisco. 2002. Calidoscopios de género: cuerpo, masculinidad y sobrevivencia en el espiritismo venezolano. Alteridades, No. 12 (23). UAM. México. pp: 83-92.

Foucault, Michel. 1977. Nietzche, genealogía, historia. In: Donald Bouchard (ed). Lenguaje, contramemoria, práctica: ensayos selectos y entrevistas. Cornell University Press. EUA.

Fuller, Norma. 1998. Reflexiones sobre el machismo en América Latina. In: Teresa de Valdés, y José Olavarría (eds). FLACSO, UNFPA. Chile. pp: 258-266.

García Canclini, Nicolás. 1989. Culturas hibridas. Estrategias para entrar y salir de la modernidad. Grijalbo, México.

Geertz, Cliford. 1987. La interpretación de las culturas. GEDISA, México.

Guasch, Óscar. 2000. La crisis de la heterosexualidad. LERTES. Barcelona. Espańa.

Gutmann, Matthew C. 1998. El Machismo. In: Teresa de Valdés y José Olavarría (eds.). Masculinidades y equidad de género en América Latina. UNFPA. FLACSO-Chile. pp: 238-257.

Herrera, Flores Joaquín. 2005. De habitaciones propias y otros espacios negados. Una teoría crítica de las opresiones patriarcales. Instituto de Derechos Humanos-Universidad de Deusto. Bilbao. País Vasco, España.

Hernández, Isabel. 1998. Identidades étnicas subordinadas e identidades masculinas hegemónicas. In: Teresa Valdés, y José Olavarría (eds). Masculinidades y equidad de género en América Latina. FLACSO, UNFPA, Chile. pp: 218-229.

Hernández Sánchez, Ernesto. 2009. Entre la memoria y el olvido: padres migrantes indígenas. In: Juan Carlos Ramírez Rodríguez y Griselda Uribe Vázquez (coords). Masculinidades, el juego de género de los hombres en el que participan las mujeres. Academia Jalisciense de Ciencias, A.C. Academia
Mexicana de Estudio de Género de los Hombres A.C. PIEGE, UNFPA, UdeG, P y V. México-España. pp: 201-215.

Huberman, Hugo Ernesto. 2013. Masculinidades y procesos de intervención con hombres, grupos mixtos, jóvenes y niños. Notas del Curso de Capacitación. Alianza EMAS-FEM. Campaña del Lazo Blanco Argentina-Uruguay. Puebla, Pue.

Izquierdo Benito, Ma. De Jesús. 2007. Lo que cuesta ser hombre: costes y beneficios de la masculinidad. In: Masculinidad y vida cotidiana. Espacios para la Igualdad. (Resúmenes). SARE-Emakunde. Donostia. País Vasco. pp: 33.

Jiménez Guzmán, Ma. Lucero. 2002. Varones: sexualidad, reproducción y paternidad. La formación de nuevos seres humanos. Decisio, Vol. I Número 2. CREFAL, México. pp: 12-14.

Kabeer, Naila.1998. Realidades trastocadas. Las jerarquías de género en el pensamiento del desarrollo. PUEG-UNAM. México.

Kimmel, Michel.1998. El desarrollo (de género) del subdesarrollo (de género): la producción simultanea de masculinidades hegemónicas y dependientes en Europa y en Estados Unidos. In: Teresa de Valdés y José de Olavarría (eds). Masculinidades y equidad de género en América Latina. FLACSO-UMFPA. Chile. pp: 207-217.

La Jornada. 2012. Hay más de 8 mil indígenas encarcelados. De la Redacción del periódico, Sección: Política. Sábado 25 de agosto de 2012, http://www.jornada.unam.mx/2012/08/25/ politica/016n3pol Revisado el 29 de marzo de 2014. 16 p.

López Moya, Martín de la C. 2010. Hacerse hombres cabales. Masculinidad entre tojolabales. México: Colección Selva Negra. Unicach/Ciesas.

Maffia, Diana. 2006. Lo que no tiene nombre. In: Disidencia sexual e identidades sexuales y genéricas. Consejo Nacional para Prevenir la Discriminación. CONAPRED. México, D.F. pp: 31-35.

Martínez Corona, Beatriz. 2000. Género, empoderamiento y sustentabilidad. Una experiencia de microempresa artesanal de mujeres indígenas. Serie PEMSA 2, GIMTRAP. México.

Martínez de Bringas, Asier. 2003. Los pueblos indígenas y el discurso de los derechos. Universidad de Deusto. Instituto de Derechos Humanos. Bilbao, España.

Mellor, Mary. 2007. Mujer, naturaleza y construcción social del hombre económico. In: Carmen Velayos; Olga Barrios; Ángela Figuerelo, y Teresa López (eds). Feminismo ecológico. Estudios multidisciplinares de género. Aquí La Fuente. Ediciones Universidad Salamanca. Salamanca, Espańa. pp: $31-52$

Miano Borriso, Marinella. 1998. Gays tras bambalinas. Historia de belleza, pasiones e identidades. Debate Feminista, Año 9, Vol. 18, Oct. pp: 186-236.

Mogrovejo Aquise, Norma; Héctor Salinas Hernández y Francesca Gargallo. 2006. Introducción. In: Disidencia sexual e identidades sexuales y genéricas. Consejo Nacional para Prevenir la Discriminación. CONAPRED. México, D.F. pp: 9-16.

Mosse, George L. 2000. La imagen del hombre. Talasa. Serie Arcoiris. Madrid, España.

Mott, Luís. 2006. Homofobia en América Latina: etnohistoria del heterrorsexismo contra los disidentes sexuales. In: Disidencia sexual e identidades sexuales y genéricas. Consejo Nacional para Prevenir la Discriminación (CONAPRED), México. pp: 37-43. 
Núñez Noriega, Guillermo. 2006. La heterogeneidad de la experiencia homoerótica: más allá de la subjetividad homosexual. In: Disidencia sexual e identidades sexuales genéricas. CONAPRED. México. pp: 45-51.

Núńez Noriega, Guillermo. 2009. Vidas vulnerables. Hombres indígenas, diversidad sexual y VIH/SIDA. México: CIAD A.C/Edamex. Recuperado de www.ciesas.edu.mx/desacatos/35\%20Indexado/saberes_1.pdf

Palma, Adriana. 2006. ¿De qué tiene que avergonzarse la Magdalena y el coronel Gisella? Zapatismo y diversidad sexual. In: Disidencia sexual e identidades sexuales genéricas. CONAPRED. México. pp: 171-181.

Páramo, Teresa. 2005. Cultura machista e identidad social. In: Rafael Montesinos (coord). Masculinidades emergentes. Porrúa, UAM-Iztapalapa. D.F. México. pp: 219-255.

Peña Jumpa, Antonio, Vicente Cabedo Mallol, y Francisco López Bárcenas. 2002. Constituciones, derecho y justicia en los pueblos indígenas de América Latina. Pontificia Universidad Católica de Perú. Fondo Editorial. Perú.

Pérez Castro-Vázquez, Juan Carlos. 2003. La variable de la masculinidad en los procesos para el desarrollo sustentable, experiencia y marco teórico. In: La Ventana, No. 17. UDG. Guadalajara, Jalisco, México. pp: 250-302.

Pérez Nasser, Elia. 2011. Dificultades y contradicciones en la configuración de las identidades nahuas de tres generaciones de hombres de la Sierra Norte de Puebla. Estudios de Caso. Tesis doctoral, Universidad Complutense. Recuperado de htpp://eprints.ucem.es/12025/1/T32599.pdf.
Ramírez Rodríguez, Juan Carlos. 2009. Ejes estructurales y temáticos de análisis del género de los hombres. Una aproximación. In: Juan Carlos Ramírez Rodríguez, y Griselda Uribe Vázquez (coord). Masculinidades. El juego de género de los hombres en el que participan las mujeres. Academia de Ciencias Jalisciense, Academia Mexicana de Estudios de Género de los Hombres A.C. PIAGE, UNFPA, U de G, P y V. México. pp: 85-112.

Rivas, Eloy. 2006. ¿La masculinidad como factor de riesgo? Crítica a los estereotipos académicos sobre el machismo desde el constructivismo social. In: Disidencia sexual e identidades sexuales genéricas. CONAPRED. México. pp: 243-251.

Rubin, Gayle. 1997. El tráfico de mujeres: notas sobre la economía política del sexo. In: Lamas Marta (comp). El género: La construcción cultural de la diferencia sexual. PUEGUNAM. Porrúa. $1^{\circ}$ Reimpresión. México.

Segal, Lynne. 2008. Los hombres tras el feminismo: ¿Qué queda por decir? In: Àngels Carabí y Joseph M. Armengol (eds). La masculinidad a debate. Icaria. Barcelona, España. pp: 155175.

Seidler, Victor. 2000. La sinrazón masculina. Masculinidad y teoría social. UNAM-PUEG-CIESAS. México.

Turner, Terence. 1999. Indigenous and Culturalist Movements in the Contemporary Global Conjunture. In: Francisco Fenández del Riego (ed). Las identidades y tensiones culturales e la modernidad. Homenaje a Xeneración Nós- VIII Congreso de Antropología de la FAAE. Asociación Galega de Antropología. Santiago de Compostela, España. pp: 52-72.

Valdés, Teresa, y José Olavarría. 1998. Masculinidades y equidad de género en América Latina. FLACSO-Chile, UNFPA. Santiago de Chile. Chile. 